\title{
PERFORMANCE ANALYSIS OF LOCAL PEKANBARU BENTONITE FOR REACTIVE SOLID APPLICATION OF MUD DRILLING
}

\author{
Novrianti ${ }^{1}$, Idham Khalid ${ }^{1}$, Richa Melysa ${ }^{1}$ \\ ${ }^{1}$ Department of Petroleum Engineering, Universitas Islam Riau
}

\begin{abstract}
Mud rheology of imported bentonite is accordance with the provisions of the API specification 13A. Indonesia have a number of areas with potential mineral content of the bentonite namely Java, Sumatra, parts of Kalimantan and Sulawesi with reserves more than 380 million tons. The use of local bentonite minerals will be more economical and efficient. To find out the quality of local bentonite minerals as a substitute for imported bentonite, it is necessary to conduct research related to the compatibility between drilling mud rheology using local bentonite and API Spec $13 \mathrm{~A}$. The minerals used in this study came from the Kulim area of the District of Tenayan Raya, Pekanbaru. SEM and XRD tests were carried out to determine the composition and structure of local minerals. Then, drilling mud rheological tests of mud using local minerals were carried out experimentally in the Laboratory. Addition of $\mathrm{Na} 2 \mathrm{CO} 3$ additive was added to the sand content test, yield point, plastic viscosity, viscosity and gel strength. Whereas for the measurement of $\mathrm{PH}$ mud in addition to using additive Na2CO3 also using CarboxyMethyl Cellulose (CMC) and barite additives. Based on an analysis of SEM and EDX, it was found that samples taken in the Kulim area of Tenayan Raya District, Pekanbaru City can be categorized as Illite fe-rich and Illite Platty. However the gel strenght mud drilling with Illite fe-rich and Illite platty without the addition of $\mathrm{Na} 2 \mathrm{CO} 3$ additives in accordance with API Spec 13A which is $1 \mathrm{lbs} / 100 \mathrm{ft}$. The yield point/plastic viscosity of drilling mud Illite fe-rich and Illite platty meets API Spec $13 \mathrm{~A}$ which is below 3 and the PH value of drilling mud with Illite fe-rich and Illite platty with the addition of CMC and barite additives meets API Spec 13A which is 9.
\end{abstract}

Keywords: Bentonite, Drilling Mud, reactive solid, Water Based Mud, Rheology

Corresponding Author: novrianti@eng.uir.ac.id

\section{INTRODUCTION}

Drilling mud is one of the main components that determines the smoothness and success of a drilling operation. (Jr., Millheim, \& Chenevert, 1986), (Adams \& Charrier, 1985). The mud system used in a drilling operation must be in accordance with the formation conditions and lithology that must be penetrated. The composition and physical properties of mud are very influential on a drilling operation, because one of the factors that determine whether or not a drilling is successful depends on the drilling mud used. Drilling speed, efficiency, safety and drilling costs depend on the drilling mud used. Physical and chemical properties of drilling mud depend on the type of chemical additives added which have different behaviors and physical characteristics. (Bleier, 1990). The best combination of these additives will provide the required functions of the drilling mud such as; carrying the cuttings from downhole to the surface, cooling and lubricating the drilling bit, reducing friction and drag, maintaining wellbore stability, preventing influx of fluids from wellbore, and forming thin and low permeable filter cake to control water losses and support holewall and also not cause damage the production zone.(Ibrahim \& Elhag, 2014).

Bentonite is used in water based mud to formulate the body of drilling mud, works as viscofier additives and reduce water losses. (Ibrahim \& Elhag, 2014). Bentonite is a reactive solid mineral that is most widely used in water-based drilling mud. (Mohammed, D, \& Richardson, 2013), (Mohammed et al., 2013). Bentonite is a smectite mineral, usually Montmorillonite(Adamis Z, 2005). Besides Montmorillonite Bentonite also contains other impurity minerals, such as quartz, Illite, cristobalite, calcite, gypsum, kaolinite and plagioclase. (Grim, 1968) (González, 2013). Bentonite Is one type of rock with the main composition of clay minerals $(85 \%)$ consisting of minerals montmorillonite $(\mathrm{Mg} 2 \mathrm{~A} 110 \mathrm{Si} 24 \mathrm{O} 60(\mathrm{OH}) 12(\mathrm{Na}$, Ca)) (Günister, İşçi, Öztekin, Güngör, \& Erim, 2004), (Rouquerol, Jean, Francoise R, 1998)

There are 2 types of bentonite: (Barton \& Karathanasis, 2002)

1. Sodium Bentonite

2. Calcium, Magnesium Bentonite 
Based on the type, bentonite is considered into two, namely:(Johnstone, Sydney J.; Johnstone, 1962), (Kutlić, Bedeković, \& Sobota, 2012) Type of Wyoming (Na-bentonite - Swelling bentonite) and Ca-bentonite non swelling bentonite.

\section{Bentonite Quality}

Bentonite quality determined mainly by four parameter: (González, 2013)

1- The content of material other than montmorillonite.

2- The type of counter-ions presents on the montmorilloniteplatelets.

3- The presence or absence of small amount of extending polymer.

4- The size and charge of the montmorillonite platelets.

Indonesia is an area that has a very large potential of bentonite reserves and is spread in almost regions, especially in the Java, Sumatra, and Kalimantan, but the utilization is not optimal. Bentonite applied as the base material for drilling mud must be in accordance with API Specification 13A standards. (American Petroleum Institute, 2010). Bentonite used in oil and gas wells in Riau comes from the island of Java and outside Indonesia. Research on the effect of bentonite in Pekanbaru on the rheology of suitable drilling mud and its additive, so that it is in accordance with API standards 13A needs to be done so that it can be attempted to exploit the potential of raw materials in Pekanbaru. Chemical composition testing was carried out by sending Clay Samples in Riau, Central Sumatra to be tested for SEM and EDX analysis to obtain the composition and structure of Clay's minerals. While Rheology testing is carried out in accordance with standard operating procedures (SOP) of the mud laboratory drilling for Petroleum Engineering of Riau Islamic University. which is then used for mud classification analysis in accordance with standard 13A.

Regional maps of Riau are found in Figure 1. Based on the Pekanbaru regional map, the research area is included in the Minas formation which consists of gravel, glacial distribution, sand and clay. With Pleistocene age estimated at \pm 1.8 million years ago.

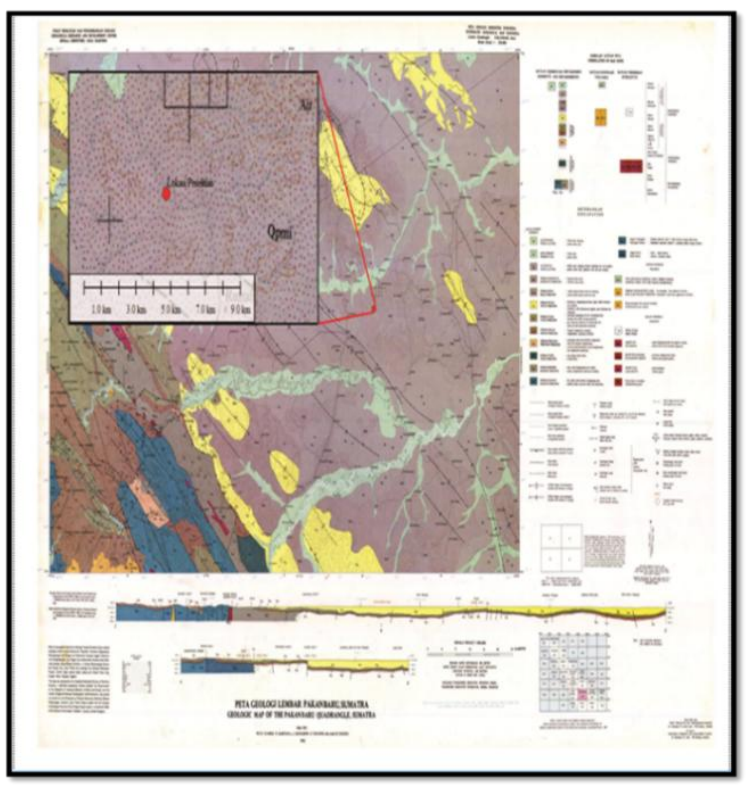

Figure 1. Geological Map of Pekanbaru (González, 2013)

\section{Materials and Method \\ Materials}

The bentonite samples were acquired from Jln. Badak, Sail Village, Tenayan Raya District, Pekanbaru City, Riau Province. Geographically the location of the sampling is located at 0 "30'23" N / 101 $31^{\circ} 45$ "E. All data used to 
evaluate Riau bentonite samples were obtained from lumps and samples with experimental procedures. The additives used for analysis are sourced from the market in Pekanbaru, namely $\mathrm{Na}_{2} \mathrm{CO}_{3}$. Laboratory equipment or tools used to destroy clay samples, $140{ }^{\circ} \mathrm{C}$ dryers are also provided to dry the sample. Sieve analysis of 200 mesh is used for sifting samples. Balance digital weighing is provided to measure. Mixer is provided to condition each mixture. Test sand content uses sand content set. Viscosity test, yield point, gel strength and plastic viscosity use FANN VG meter and mars funnel. PH using HPHT filter press.

\section{RESEARCH METHODOLOGY}

The bentonite sample is dried at $140{ }^{\circ} \mathrm{C}$ to remove moisture, volatile and flammable organic matter in the sample. The heated sample was smoothed using a blender and filtered using a 200 mesh sieve analysis. The composition of drilling samples for sand content, viscosity test, yield point, gel strength and plastic viscosity testing are at table 1 and table 2. While the sample composition used for PH sample are in table 3 and table 4

Table 1. Composition of Clay Illit Fe-rich + Na2CO3 ( sample a)

\begin{tabular}{cl}
\hline Name & Composition \\
\hline S1 & Clay Illit Fe-rich +350 cc aquadest \\
\hline S2 & Clay Illit Fe-rich +350 cc aquadest $+5 \% \mathrm{Na} 2 \mathrm{CO} 3$ \\
\hline S3 & Clay Illit Fe-rich $+350 \mathrm{cc}$ aquadest $+10 \% \mathrm{Na} 2 \mathrm{CO} 3$ \\
\hline S4 & Clay Illit $F e$-rich +350 cc aquadest $+15 \% \mathrm{Na} 2 \mathrm{CO} 3$ \\
\hline S5 & Clay Illit $F e$-rich +350 cc aquadest $+20 \% \mathrm{Na} 2 \mathrm{CO} 3$ \\
\hline
\end{tabular}

Table 2. Composition of Clay Illit Platty + Na2CO3 ( sample b)

\begin{tabular}{cl}
\hline Name & Composition \\
\hline S1 & Clay illit platty +350 cc aquadest \\
\hline S2 & Clay illit platty +350 cc aquadest $+5 \% \mathrm{Na} 2 \mathrm{CO} 3$ \\
\hline S3 & Clay illit platty $+350 \mathrm{cc}$ aquadest $+10 \% \mathrm{Na} 2 \mathrm{CO} 3$ \\
\hline S4 & Clay illit platty +350 cc aquadest $+15 \% \mathrm{Na} 2 \mathrm{CO} 3$ \\
\hline S5 & Clay illit platty +350 cc aquadest $+20 \% \mathrm{Na} 2 \mathrm{CO} 3$ \\
\hline
\end{tabular}

Table 3. Composition of Clay Illit Fe-rich $+\mathrm{Na} 2 \mathrm{CO} 3$ and additive ( sample a)

\begin{tabular}{cl}
\hline Name & Composition \\
\hline S1 & Clay Illit Fe-rich $+350 \mathrm{cc}$ aquadest \\
\hline S2 & Clay Illit Fe-rich $+350 \mathrm{cc}$ aquadest $+5 \% \mathrm{Na} 2 \mathrm{CO} 3$ \\
\hline S3 & Clay Illit Fe-rich $+350 \mathrm{cc}$ aquadest $+10 \% \mathrm{Na} 2 \mathrm{CO} 3$ \\
\hline S4 & Clay Illit Fe-rich $+350 \mathrm{cc}$ aquadest $+15 \% \mathrm{Na} 2 \mathrm{CO} 3$ \\
\hline S5 6 Clay Illit Fe-rich $+350 \mathrm{cc}$ aquadest $+20 \% \mathrm{Na} 2 \mathrm{CO} 3$ \\
\hline S7 & Clay Illit Fe-rich +350 cc aquadest + additive CMC \\
\hline
\end{tabular}

Table 4. Composition of Clay Illit Platty $+\mathrm{Na} 2 \mathrm{CO} 3$ and additive ( sample b) 
Novrianti, Idham khalid, Richa Melysa /JEEE Vol. 07 No. 02/2018

\begin{tabular}{cl}
\hline Name & Composition \\
\hline S1 & Clay illit platty $+350 \mathrm{cc}$ aquadest \\
\hline S2 & Clay illit platty +350 cc aquadest+ $5 \%$ Na2CO3 \\
\hline S3 & Clay illit platty $+350 \mathrm{cc}$ aquadest $+10 \% \mathrm{Na} 2 \mathrm{CO} 3$ \\
\hline S4 & Clay illit platty $+350 \mathrm{cc}$ aquadest+ $15 \% \mathrm{Na} 2 \mathrm{CO} 3$ \\
\hline S5 & Clay illit platty $+350 \mathrm{cc}$ aquadest $+20 \% \mathrm{Na} 2 \mathrm{CO} 3$ \\
\hline S6 & Clay Illit Fe-rich +350 cc aquadest + additive CMC \\
\hline S7 & Clay Illit Fe-rich +350 cc aquadest + additive Barite \\
\hline
\end{tabular}

For sand content testing after sample is finished, filling the measuring tube with drilling mud. Add water to the next limit. Pour the mixture into a filter. the liquid will flow through the filter. Install the funnel on the top side of the filter. Gently flip the set of equipment and insert the end of the funnel into the measuring cup. Throw sand into the tube by spraying water through the filter until all the sand accumulates in the measuring cup. Let the sand settle. From the scale in the tube, read the percent volume of the sand that settles

Gel strenght test for mud is stirred with Fann VG at a speed of 600 RPM for 10 seconds. Turn on the Fann VG, then let the mud stand for 10 seconds. After 10 seconds, drive the rotor at 3 RPM. Read the maximum deviation on the pointer scale. Re-stir the mud with Fann VG at a rotor speed of 600 RPM for 10 seconds.Repeating the work steps above for gel strength is 10 minutes (for 10 minutes gel strength, 10 minutes of mud bathing). For the mud cake test pour the mixture of mud into the cylinder and immediately close it tightly on the HPHT then drain the air with a pressure of 100 psi. Record the filtrate volume as a function of time with the stopwatch. Observation interval every minute in the first 20 minutes, then 5 minutes for the next 20 minutes. Also note the filtrate volume at 7.5 minutes. Determine the thickness of the mud cake Measurement of PH mud drilling by means of PH paper dipped in mud and then removed after it was waited until the PH paper was dry and from the PH paper that was dried up was obtained the $\mathrm{pH}$ value of the sample mud drilling

\section{Results}

The sample testing process found in the Kulim area of Tenayan Raya Pekanbaru sub-district is done by refining the sample by using sieve analysis, the filtering size used is 100 mesh. In plain view, seen on the surface of the clay color found in Kulim sub-district, Tenayan Raya Pekanbaru, it is divided into two: clay samples that are white (sample a) and red clay (sample b). The results of SEM and EDX testing for both samples can be seen in Figure 2 and Figure 3 and Table 5 and Table 6 below.
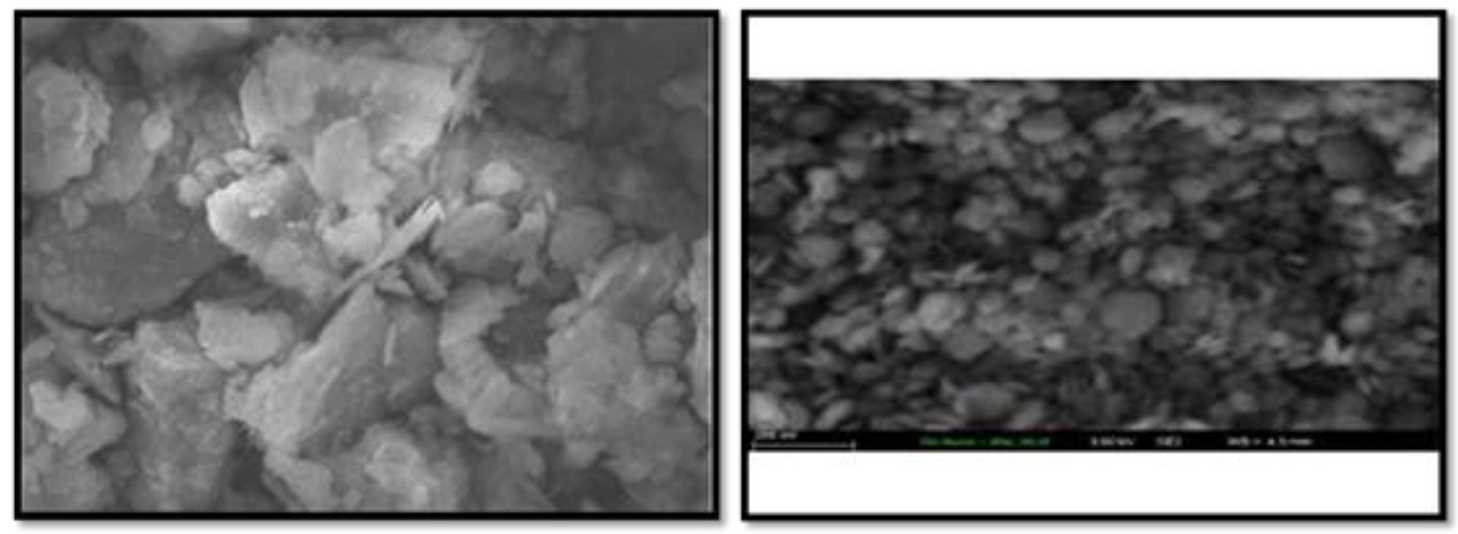

Figure 2 Analysis of clay SEM samples a 
Table 5. Chemical Properties clay a

\begin{tabular}{|c|c|c|c|c|c|c|c|c|c|c|c|}
\hline Sampel/ Location & $\underset{\%}{\mathrm{MgO}}$ & $\begin{array}{c}\mathrm{Al}_{2} \mathrm{O}_{3} \\
\%\end{array}$ & $\begin{array}{c}\mathrm{SiO}_{2} \\
\%\end{array}$ & $\mathrm{C} \%$ & $\begin{array}{c}\mathrm{CaO} \\
\%\end{array}$ & $\begin{array}{l}\mathrm{TiO} \\
2 \% \\
\end{array}$ & $\begin{array}{c}\mathrm{Fe}_{2} \mathrm{O}_{3} \\
\%\end{array}$ & $\mathrm{C} \%$ & $\begin{array}{c}\mathrm{CuO} \\
\%\end{array}$ & $\begin{array}{c}\mathrm{Na} 2 \mathrm{O} \\
\%\end{array}$ & $\begin{array}{l}\mathrm{K} 2 \mathrm{O} \\
(\%)\end{array}$ \\
\hline $\begin{array}{c}\text { Bentonite ( } \\
\text { Wyoming)/ USA }\end{array}$ & 1.92 & 22.84 & 66.11 & 0.56 & 1.32 & 0.55 & 6.51 & $N D$ & $N D$ & 2.2 & ND \\
\hline $\begin{array}{c}\text { Illit Fe-rich ( Mid- } \\
\text { Sumatra) }\end{array}$ & 0.66 & 28,08 & 49.3 & 3.02 & $N D$ & 1.13 & 1.18 & 14.52 & 1.43 & ND & $\mathrm{ND}$ \\
\hline
\end{tabular}
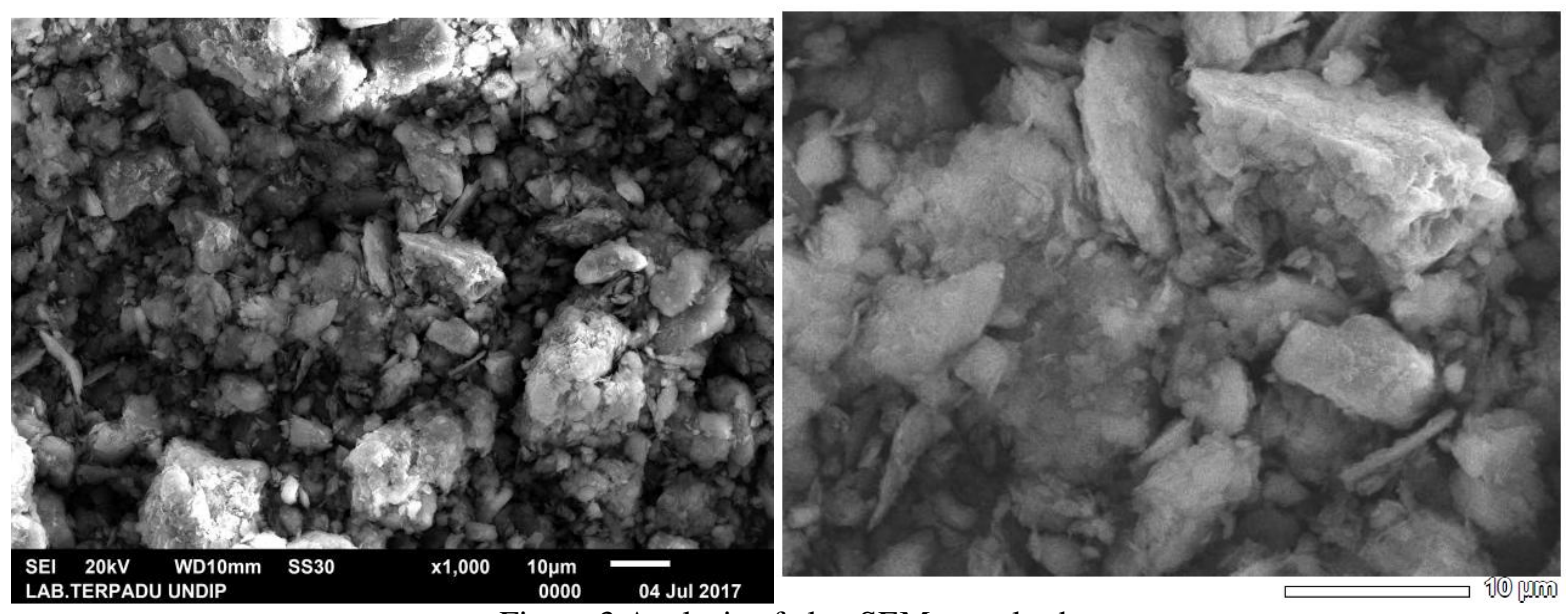

Figure 3 Analysis of clay SEM samples b

Table 6. Chemical Properties clay b

\begin{tabular}{cccccccccccc}
\hline $\begin{array}{c}\mathrm{MgO} \\
\text { Sampel/ Location }\end{array}$ & $\begin{array}{c}\mathrm{Al}_{2} \mathrm{O}_{3} \\
\%\end{array}$ & $\begin{array}{c}\mathrm{SiO}_{2} \\
\%\end{array}$ & $\mathrm{C} \%$ & $\begin{array}{c}\mathrm{CaO} \\
\%\end{array}$ & $\begin{array}{c}\mathrm{TiO}_{2} \\
\mathrm{Fe}_{2} \mathrm{O}_{3} \\
\%\end{array}$ & $\begin{array}{c}\mathrm{C} \% \\
\%\end{array}$ & $\begin{array}{c}\mathrm{Na} 2 \mathrm{O} \\
\%\end{array}$ & $\mathrm{~K} 2 \mathrm{O}$ \\
\hline $\begin{array}{c}\text { Bentonite ( } \\
\text { Wyoming)/ USA }\end{array}$ & 1.92 & 22.84 & 66.11 & 0.56 & 1.32 & 0.55 & 6.51 & $N D$ & $N D$ & 2.2 & $\mathrm{ND}$ \\
\hline $\begin{array}{c}\text { Illite Platy (Mid- } \\
\text { Sumatera) }\end{array}$ & $\mathrm{ND}$ & 25,41 & 46.78 & 20,73 & $\mathrm{ND}$ & 0.85 & 3.15 & 20.73 & 1.41 & $\mathrm{ND}$ & 1.67 \\
\hline
\end{tabular}

\section{Rheological Drilling Mud}

\section{a. Sand Content}

Based on the results of the analysis of SEM and EDX, clay a and clay b samples are the Bentonite Ca category. Bentonite used in industry is a category of $\mathrm{Na}$ Bentonite so the additive $\mathrm{Na} 2 \mathrm{CO} 3$ needs to be added for sand content testing. The Na minerals contained in $\mathrm{Na} 2 \mathrm{CO} 3$ function to bind drilling mud samples, helping swelling properties in drilling mud so that the drilling mud does not settle immediately. The concentration of $\mathrm{Na} 2 \mathrm{CO} 3$ used for each clay a and clay b is 5\%,10\%, $15 \%$ and $20 \%$. As for the graph of sand content test and for illie ferich and illite platty samples can be seen in Figure 4 the following: 


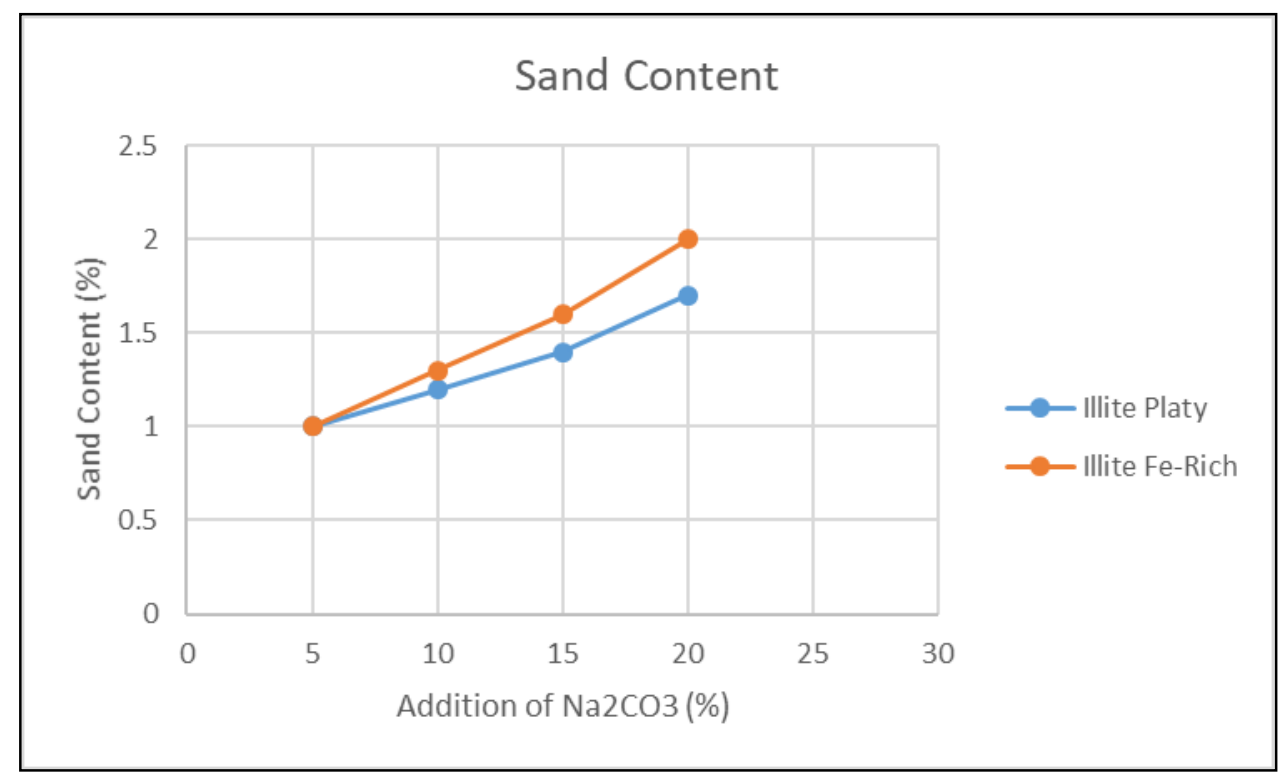

Figure 4. Sand Content of illite ferich and illite platty

The addition of Na2CO3 concentration has an effect on the sand content of drilling mud that consists of illite ferich and illite platty. The higher the $\mathrm{Na} 2 \mathrm{CO} 3$ concentration used, the higher the sand content value obtained for the two samples. This happens because with the addition of $\mathrm{Na} 2 \mathrm{CO} 3$, the resulting drilling mud sample is easier to lift the drilling cut. $\mathrm{Na} 2 \mathrm{CO} 3$ acts as a flux in quartz that is widely available in drilling mud drilling.

\section{b. Gel strenght}

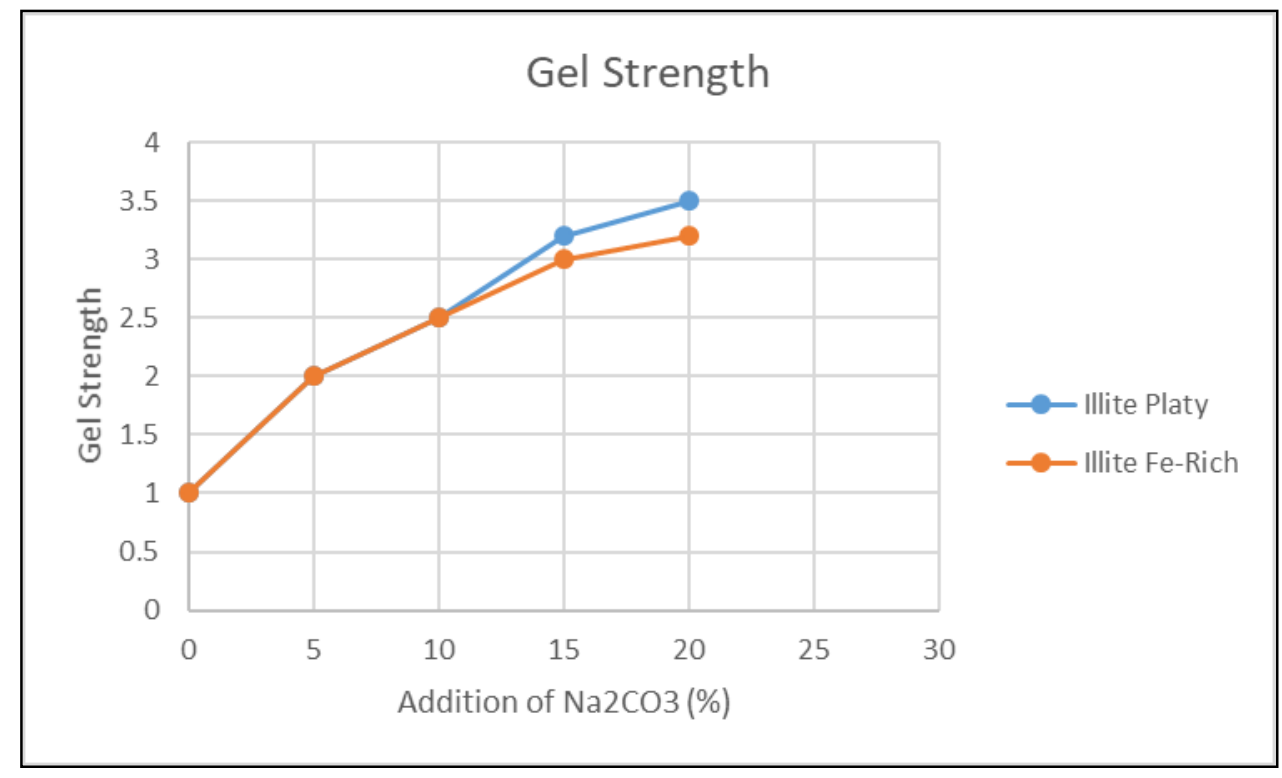

Figure 5. Gel Strenght of illite ferich and illite platty

In the gel strenght test, sample illite ferich and illite platty sample are added with Na2CO3. Figure 5 are gel strenght values for illite fe-rich and illite platty. Based on the picture it can be seen that the addition of the Na2CO3 composition has an effect on the increase in the gel strenght. The Value of gel strenght based on Spesification API 
$13 \mathrm{~A}$ is $2 / 3-4 / 5 \mathrm{lbs} / 100 \mathrm{ft}$. Illite ferich and illite platty no need addition $\mathrm{Na} 2 \mathrm{CO} 3$ to match with Spesification API $13 \mathrm{~A}$.

\section{c. Drilling Mud viscosity, Plastic viscosity and Yield point Tests}

Figure 6,7 and 8 are viscosity, plastic viscosity and yield point values for illite ferich and illite platty with additions $0 \%, 5 \%, 10 \%, 15 \%$ and 20\% additive $\mathrm{Na} 2 \mathrm{CO} 3$. Based on Figure 6, 7 and 8 seen that $\mathrm{Na} 2 \mathrm{CO} 3$ affect the increase of viscosity, plastic viscosity and yield point. The viscosity value obtained from illite ferich and illite platty not match with Spesification API 13 A. addition of additives does not cause the viscosity value obtained according to Spesification API 13 A

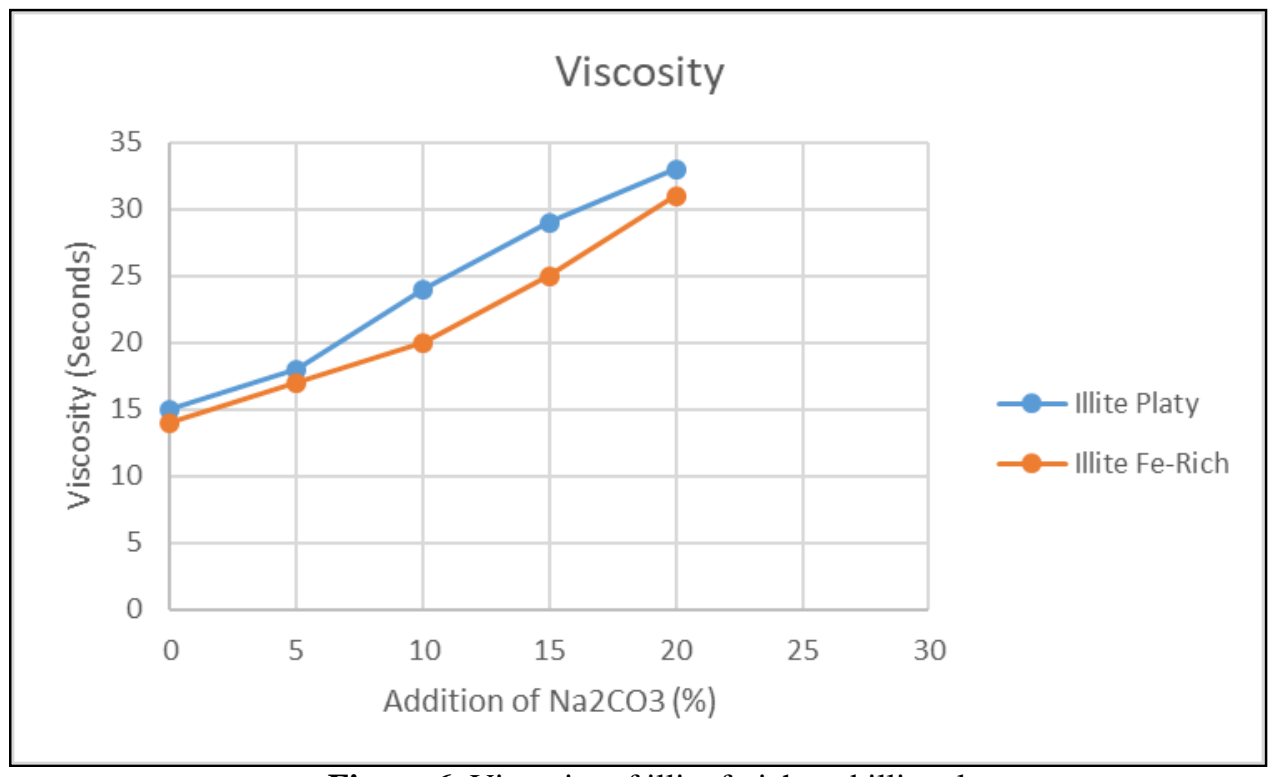

Figure 6. Viscosity of illite ferich and illite platty

$\mathrm{Na} 2 \mathrm{CO} 3$ functions as an anticougulan, which can prevent deposits in drilling mud, which can also make viscosity increase and evenly along with the addition of percent of concentration. This same phenomenon also occurs in plastic viscosity and yield points which can be seen in Figure 7 and Figure 8 
Novrianti, Idham khalid, Richa Melysa /JEEE Vol. 07 No. 02/2018

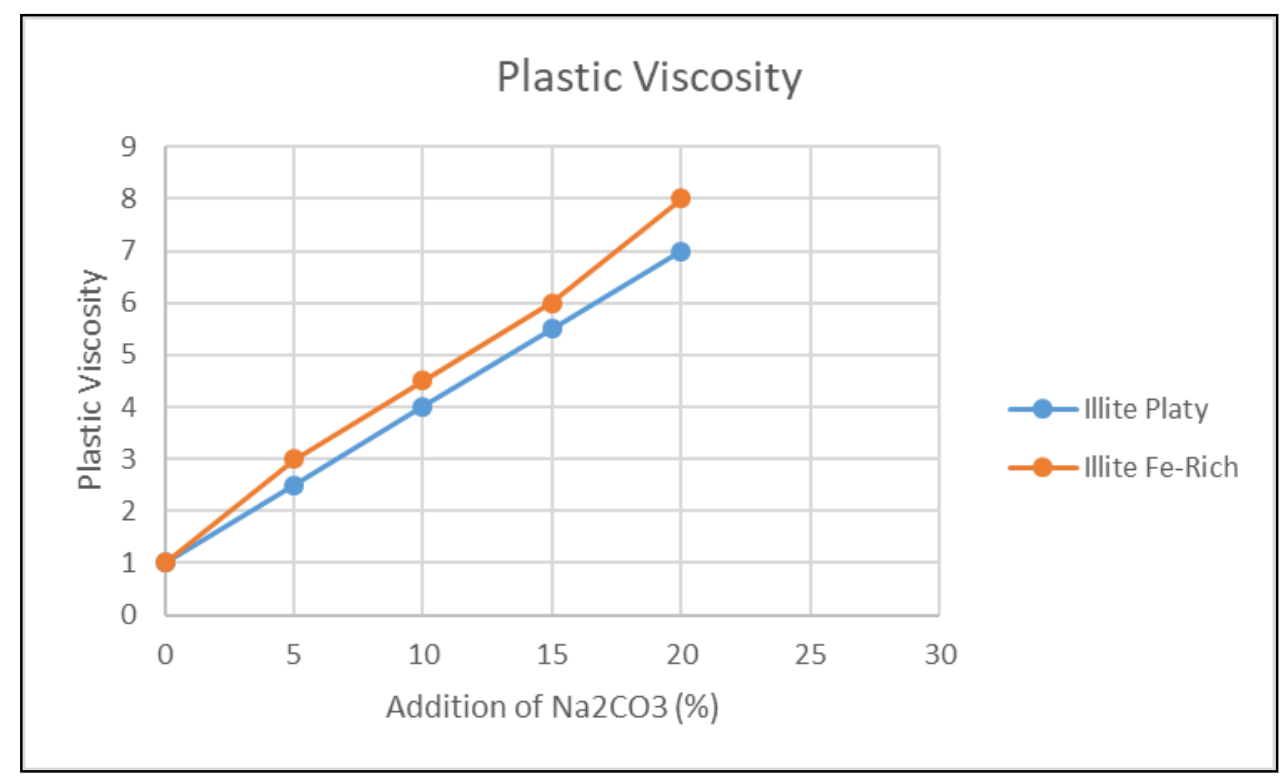

Figure 7. Plastic Viscosity of illite ferich and illite platty

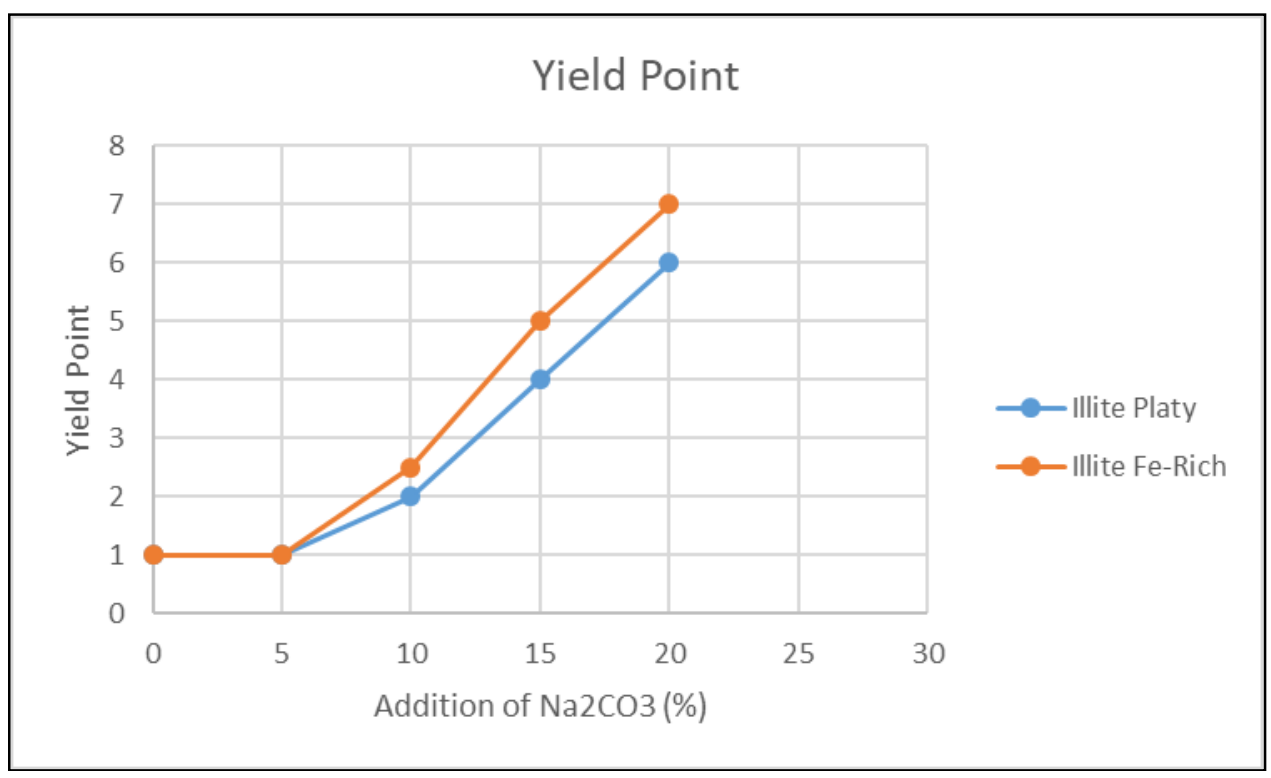

Figure 8. Yield Point of illite ferich and illite platty

\section{d. PH Test of Drilling Mud}

Table 7. PH Sample Clay a (Clay Illit Fe-rich)

\begin{tabular}{clc}
\hline Name & Composition & PH \\
\hline S1 & Clay Illit Fe-rich +350 cc aquadest & 7 \\
S2 & Clay Illit Fe-rich +350 cc aquadest $+5 \% \mathrm{Na} 2 \mathrm{CO} 3$ & 12 \\
S3 & Clay Illit Fe-rich +350 cc aquadest $+10 \% \mathrm{Na} 2 \mathrm{CO} 3$ & 12 \\
S4 & Clay Illit Fe-rich $+350 \mathrm{cc}$ aquadest $+15 \% \mathrm{Na} 2 \mathrm{CO} 3$ & 12 \\
S5 & Clay Illit Fe-rich $+350 \mathrm{cc}$ aquadest $+20 \% \mathrm{Na} 2 \mathrm{CO} 3$ & 12 \\
S6 & Clay Illit Fe-rich +350 cc aquadest + additive CMC & 9
\end{tabular}


Novrianti, Idham khalid, Richa Melysa/JEEE Vol. 07 No. 02/2018

S7 Clay Illit Fe-rich +350 cc aquadest + additive Barite

9

Table 8. PH Sample Clay b (Clay Illit Platty)

\begin{tabular}{clc}
\hline Name & Composition & PH \\
\hline S1 & Clay Illit Platty +350 cc aquadest & 7 \\
S2 & Clay Illit Platty+ 350 cc aquadest $+5 \% \mathrm{Na} 2 \mathrm{CO} 3$ & 12 \\
S3 & Clay Illit Platty $+350 \mathrm{cc}$ aquadest $+10 \% \mathrm{Na} 2 \mathrm{CO} 3$ & 12 \\
S4 & Clay Illit Platty+ 350 cc aquadest $+15 \% \mathrm{Na} 2 \mathrm{CO} 3$ & 12 \\
S5 & Clay Illit Platty+ 350 cc aquadest $+20 \% \mathrm{Na} 2 \mathrm{CO} 3$ & 12 \\
S6 & Clay Illit Platty+ 350 cc aquadest + additive CMC & 9 \\
S7 & Clay Illit Platty+ 350 cc aquadest + additive Barite & 9 \\
\hline
\end{tabular}

The Result of testing PH drilling mud seen at table 7 and table 8. Based on the table is known that value of PH drilling mud for illite ferich and illite platty are same and not influenced with addition additive $\mathrm{Na} 2 \mathrm{CO} 3, \mathrm{CMC}$ and barite.

e. Comparison of Standard API Specific Drilling Mud Rheology 13 A with Illite Ferich and Illite Platty

Table 9. Comparation the rheological of local bentonite with Wyoming bentonite

\begin{tabular}{lccc}
\hline \multicolumn{1}{c}{ Requirements } & Bentonite & $\begin{array}{l}\text { Clay Illit Fe- } \\
\text { rich ( Sample Clay Illit Platty } \\
\text { Clay a) }\end{array}$ & $\begin{array}{l}\text { (sample Clay b) } \\
\text { (sater, } \mathrm{cm}^{3}\end{array}$ \\
\hline Clay, $\mathrm{g} / 350 \mathrm{~cm}^{3}$ & 350 & 350 & 350 \\
\hline Test For Spec: & 22,5 & 22,5 & 22,5 \\
Density, ppg & 8,6 & & \\
\hline YP/PV ratio, Maximum & 3 & 8,6 & 8,7 \\
\hline Gel Strength, lbs/100ft & $2 / 3-4 / 5$ & 1 & 1 \\
\hline pH & $8.5-10$ & 1 & 1 \\
\hline
\end{tabular}

\section{CONCLUTION}

1. Based on the results of the analysis of SEM and EDX shows that samples a and sample $b$ are illite ferich and illite platty.

2. Based on test rheological test in the laboratory, the results obtained showed that the addition of additive $\mathrm{Na} 2 \mathrm{CO} 3$ had an effect on the increase in sand content, gel strenght, viscosity, plastic viscosity, yield point and $\mathrm{PH}$ drilling mud.

3. Based on the rheological test results of drilling mud consisting of viscosity, yield points / plastic viscosity, gel strenght and PH clay samples (Clay Illit Fe-rich) and clay b (Clay Illit platty) samples are still in the API Specification 13 standard range A 
Novrianti, Idham khalid, Richa Melysa /JEEE Vol. 07 No. 02/2018

\section{ACKNOWLEDGMENTS}

This research was supported by Direktorat Riset dan Pengabdian Masyarakat Direktorat Jenderal Penguatan Riset dan Pengembangan Kementerian Riset, Teknologi, dan Pendidikan Tinggi with contract no: 133/KONTRAK/LPPM/2-2018. Author also wish to thank Universitas Islam Riau (UIR), Indonesia, for the encouragement of writing this paper.

\section{REFERENCES}

Adamis Z, W. B. R. (2005). Environmental health criteria 231: Bentonite, kaolin, and selected clay minerals. Environmental Health Criteria, (231). https://doi.org/10.1016/0043-1354(85)90052-1

Adams, N. J., \& Charrier, T. (1985). Drilling engineering: A complete well planning approach.

American Petroleum Institute. (2010). API Specification 13A. Purchasing Guidelines Handbook, (August 2010), 7-58. https://doi.org/10.1002/ejoc.201200111

Barton, C. D., \& Karathanasis, A. D. (2002). CLAY MINERALS, United States Department of Agriculture Forest Service, Aiken, South Carolina, U.S.A \& University of Kentucky, Lexington, Kentucky, U.S.A. https://doi.org/10.1081/E-ESS-120001688

Bleier, R. (1990). Selecting a Drilling Fluid. Journal of Petroleum Technology, 42(July), 832-834. https://doi.org/10.2118/20986-PA

González, S. S. (2013). The swelling pressure of bentonite and sand mixtures. Retrieved from http://bucserver01.unican.es/xmlui/handle/10902/2192

Grim. (1968). Clay Moneralogy, Ralph E Grim.pdf. NewYork: New York Mc Graw Hill.

Günister, E., İşçi, S., Öztekin, N., Güngör, N., \& Erim, F. B. (2004). Influence of Cationic Polymers on The Rheological Behavior of Bentonite Clay Suspensions, (December2014). https://doi.org/10.4028/www.scientific.net/KEM.264-268.1411

Ibrahim, M., \& Elhag, M. (2014). Development of Stable Bentonite for Drilling Fluid Formulations Using Local Sources Petroleum Engineering, (December).

Johnstone, Sydney J.; Johnstone, M. G. (1962). Minerals for the chemical and allied industries. https://doi.org/10.1111/cobi.12190

Jr., A. T. B., Millheim, K. K., \& Chenevert, M. E. (1986). Bourgoyne_A.T._-_Applied_Drilling_Engineering.pdf.

Kutlić, A., Bedeković, G., \& Sobota, I. (2012). Bentonite Processing Oplemenjivanje Bentonita. RudarskoGeološko-Naftni Zbornik UDC, 24, 61-65.

Mohammed, A. S., D, C. V. P., \& Richardson, D. (2013). Range of Rheological Properties for Bentonite Drilling Muds. Center for Innovative Grounting Material and Technology, (ii), 5-6.

Rouquerol, Jean, Francoise R, K. S. (1998). Adsorpsion by Powdwers and Porous Solids 1.pdf. 